\title{
Influence of phosphorus on the arsenic uptake by tomato (Solanum lycopersicum L) irrigated with arsenic solutions at four different concentrations
}

\author{
M. Pigna ${ }^{1}$, A.G. Caporale ${ }^{1}$, V. Cozzolino ${ }^{1}$, C. Fernández López ${ }^{2}$, M.L. Mora ${ }^{3}$, A. Sommella ${ }^{1}$ \\ and A. Violante ${ }^{1 *}$ \\ ${ }^{1}$ Dipartimento di Scienze del Suolo, della Pianta, dell'Ambiente e delle Produzioni Animali, Università degli \\ Studi di Napoli Federico II, Portici, Italy. ${ }^{2}$ Cátedra de Edafología. Facultad de Ciencias Agrarias. Universidad \\ Nacional del Nordeste. Sargento Cabral 2131. Corrientes. Argentina. ${ }^{3}$ Departamento de Ciencias Químicas y \\ Recursos Naturales, and Scientific and Technological Bioresource Nucleus (BIOREN-UFRO), Universidad de \\ La Frontera,Temuco, Chile.*Corresponding author: violante@unina.it
}

\begin{abstract}
We have studied the uptake and distribution of arsenic (As) and phosphorus $(\mathrm{P})$ in roots, shoots and berries of tomato plants, grown on uncontaminated soil, irrigated with As-contaminated solutions at four concentrations $\left(0,0.5,2\right.$ and $\left.4 \mathrm{mg} \mathrm{L}^{-1}\right)$, in presence or absence of $\mathrm{P}$ fertilization.

The biomass of tomato plants decreased with increasing As concentration in irrigation water, especially tomato berries. In addition, the reduction of biomasses was significantly greater in plants non-fertilized with P. The beneficial effect generated with the $\mathrm{P}$ addition indicated that this nutrient played an important role in alleviating As toxicity in tomato plants. The higher the As concentration in irrigation water the higher the As concentration in plant tissues; most of the As absorbed by plants was accumulated in their roots. Phosphorus application has allowed to reduce As translocation toward tomato berries, enhancing plant $\mathrm{P}$ status. These observations may be useful for certain areas of the World, in which As-contaminated waters are used for agricultural purposes.
\end{abstract}

Keywords: tomato, arsenic, uptake, phosphorus fertilization, contamination. 


\section{Introduction}

Arsenic (As) is a carcinogenic metalloid ubiquitous in the environment, because of natural processes as well as anthropogenic activities, such as mining, smelting, pesticide application, which have contributed to increase the As concentration in soils and groundwaters of many areas around the World (Smith et al., 1998; Naidu et al., 2006; Lu et al., 2010). The As concentrations found in natural water bodies range from less than $0.5 \mathrm{mg} \mathrm{L}^{-1}$ to more than $5000 \mathrm{mg} \mathrm{L}^{-1}$ (Mandal and Suzuki, 2002). High As concentrations in groundwaters have been found in Argentina, Chile, Mexico, China, Hungary, West Bengal (India), Bangladesh and Vietnam (Smith et al., 1998). The latest estimates suggested that 30-35 and 6 million people in Bangladesh and West Bengal, respectively, are exposed to high level (more than $50 \mathrm{mg} \mathrm{L}^{-1}$ ) of As in their drinking waters (Chakrabarti et al., 2002; Mandal and Suzuky, 2002). In some areas of Italy hazardous As concentrations in groundwaters, higher than the recommended threshold (10 $\left.\mathrm{mg} \mathrm{L}^{-1}\right)$ set by the World Health Organization (WHO, 2004), have been found. For example, more than $50 \mathrm{mg} \mathrm{L}^{-1}$ has been identified in many groundwaters of Lazio (an Italian region), where 91 towns and villages (among Rome, Viterbo and Latina provinces) with more than 250.000 people are at serious risk.

It is becoming evident that ingestion of drinking water is not the only elevated source of As to the human diet. Long-term use of As-contaminated waters for irrigation has resulted in elevated As level in agricultural soils (Meharg and Rahman, 2003; Roychowdhury et al., 2005; Williams et al., 2005). To evaluate the possible health risk to humans consuming crops irrigated with As-contaminated waters, information is needed regarding the soil-to-plant transportation of As and to minimize the accumulation of As in plants consumed directly by humans, farm animals or wildlife (Meharg and Hartley-Whitaker, 2002; Pigna et al., 2010). Apart from the health risk, the presence of As in irrigation water or in soil at an elevated level could hamper normal growth of plants with toxicity symptoms such as biomass reduction (Carbonell-Barrachina et al., 1997) and yield losses (Jiang and Singh, 1994).

It is well known that chemical behaviour of arsenate $\left(\mathrm{AsO}_{4}\right)$ is similar to that of phosphate $\left(\mathrm{PO}_{4}\right)$. Arsenate can act as a $\mathrm{PO}_{4}$ analogue with respect to transport across root plasma membrane, with $\mathrm{PO}_{4}$ competing much more effectively for transport sites (Meharg, 1994). The effect of $\mathrm{PO}_{4}$ on the sorption/ desorption processes of As in soil environments has received great attention, being $\mathrm{PO}_{4}$ commonly added as crop fertilizer. Many authors showed that $\mathrm{AsO}_{4}$ may be only partially removed from soil colloids by $\mathrm{PO}_{4}$, even if large amounts of $\mathrm{PO}_{4}$ are applied (Smith et al., 1998; Frankenberger, 2002; Violante and Pigna, 2002). Plant uptake of As has been shown to increase upon P application in pot experiments (Jiang and Singh, 1994) and at field scale (Small and McCants, 1962). Peryea (1998) reported increased As solubility and phytoavailability on P-fertilizer application to soils. On the contrary, application of $\mathrm{PO}_{4}$ was reported to decrease bioavailability of As in soils by Hanada et al. (1975). However, further investigations on the influence of $\mathrm{P}$ application to As-contaminated systems, in which food plants are grown, are still necessary (Pigna et al., 2010).

In Italy, tomato is one of the most cultivated food plant (more than 70,000 ha for year). The production amounted to 4,900,000 tons of tomatoes for processing $(43.7 \%$ in Northern Italy, $7 \%$ in the Centre and $49.3 \%$ in the Southern Italy). From 2006 to 2010, Italy has produced on average 6.5 milion tons of tomatoes (fresh tomato + tomato to processing), equal to $38 \%$ of the entire UE productions (Agroalimentare 
News, 2011). Arsenic toxic species may be accumulated in tomato tissues and, consequently, could enter in human food chain through the ingestion of its berries. Therefore, we carried out greenhouse experiments to evaluate the influence of $\mathrm{P}$ fertilization on the: i) growth of tomato plants (Solanum lycopersicum L., cv. Piennolo), cultivated on As-uncontaminated soil irrigated with solutions containing arsenite $\left(\mathrm{AsO}_{3}\right)$ at four different concentrations and ii) As uptake by plants and its partitioning among different tissues (roots, shoots and tomato berries).

\section{Materials and Methods}

\subsection{Soil preparation and characterization}

The As-uncontaminated soil used in the experiments was collected from the sub-surface layer $(0-30 \mathrm{~cm})$ of a natural grassland in Portici, Italy; its physical and chemical properties are reported in Table 1. After air-drying, the soil samples for cultivation and chemical analyses were passed through 5 and $2 \mathrm{~mm}$ mesh sieves, respectively. Soil fractions were separated by pipette and sieving following pre-treatment with $\mathrm{H}_{2} \mathrm{O}_{2}$ to oxidize organic matter. Soil $\mathrm{pH}$ was measured by potentiometry in distilled water (1:2.5 soil: water ratio). Organic $\mathrm{C}$ content of soil was determined by wet digestion with a modified Walkley-Black procedure. For determination of CEC the soil was extracted with $1 \mathrm{M} \mathrm{NH}_{4} \mathrm{OAc}$ at $\mathrm{pH}$ 7.0. Total soil $\mathrm{N}$ was determined using a NCS auto-analizer (NA 1500 Series 2). Available $\mathrm{P}$ concentration was determined by colorimetric method using $0.5 \mathrm{M} \mathrm{NaHCO}_{3}$ as the extractant (Olsen method) (Jackson, 1974). The As concentration in digested soil was determined by Inductively Coupled Plasma Atomic Emission Spectroscopy (ICP - AES, Varian, Liberty 150).
Table 1. Physical and chemical properties of the As uncontaminated soil.

\begin{tabular}{lc}
\hline Soil properties & Values \\
\hline Coarse sand $\left(\mathrm{g} \mathrm{kg}^{-1}\right)$ & 131 \\
Fine sand $\left(\mathrm{g} \mathrm{kg}^{-1}\right)$ & 388 \\
$\mathrm{Silt}\left(\mathrm{g} \mathrm{kg}^{-1}\right)$ & 275 \\
Clay $\left(\mathrm{g} \mathrm{kg}^{-1}\right)$ & 206 \\
Soil $\mathrm{pH}\left(\right.$ in $\left._{2} \mathrm{O}\right)$ & 6.3 \\
Organic Carbon $(\%)$ & 1.6 \\
CEC (mequiv/100 g) & 18.5 \\
Available $\mathrm{P}\left(\mathrm{P}_{2} \mathrm{O}_{5}, \mathrm{mg} \mathrm{kg}^{-1}\right)$ & 13.5 \\
Total Nitrogen $(\%)$ & 0.12 \\
Total As $\left(\mathrm{mg} \mathrm{kg}^{-1}\right)$ & 6.8 \\
\hline
\end{tabular}

\subsection{Experimental conditions}

Experiments were conducted from April 2011 to July 2011 in an unheated greenhouse. Tomato plants (Solanum lycopersicum L., cv. Piennolo) were grown in pots filled with $12 \mathrm{~kg}$ of the uncontaminated soil; they were planted at a density of 3 seeds per pot, sown directly in the pots and irrigated with water during the first 2 weeks. After this period the seedlings were thinned to 1 per pot and irrigated with water containing sodium arsenite $\left(\mathrm{Na}_{2} \mathrm{HAsO}_{3}\right)$ at four different concentrations: 0 (As control treatment), 0.5, 2, and $4 \mathrm{mg} \mathrm{As} \mathrm{L}{ }^{-1}$. The range of As concentrations was chosen to encompass the concentrations occurring in underground waters of the As-affected areas of World. Arsenic-contaminated waters were added as required to maintain $60 \%$ water holding capacity. All the pots were fertilized every 2 weeks with $80 \mathrm{~mL}$ of nutrient solution containing $30 \mathrm{mM}$ of $\mathrm{NH}_{4} \mathrm{NO}_{3}$ and $25 \mathrm{mM}$ of $\mathrm{K}_{2} \mathrm{SO}_{4}$. Furthermore, in half of the pots $6 \mathrm{mM}$ of $\mathrm{K}_{2} \mathrm{HPO}_{4}$ was included in the nutrient solution in order 
to evaluate the influence of $\mathrm{P}$ on As uptake by tomato plants and then, the experimental design also provided 2 levels of $\mathrm{P}$ application, without $\mathrm{P}(\mathrm{P}-)$ and with $\mathrm{P}(\mathrm{P}+)$. The design was completely randomized and re-arranged every day, and each treatment was replicated 4 times to give a total of 32 pots. Irrigation was stopped 1 week before harvest.

Aboveground biomass was removed by cutting the base of the plant 3-4 $\mathrm{cm}$ above the soil surface (to avoid basal tissue contaminated by applied As solution), which was then separated into shoots (stems plus leaves) and berries sub-samples. The fresh tissues of the bean plants were weighed, washed with tap water, rinsed twice with deionized water in order to remove soil residues and then dried to a constant weight in the oven for two days at $70^{\circ} \mathrm{C}$.

Roots, shoots and tomato berries were analyzed for total concentration of As and P. All samples were ground using a PM 200 ball mill (Retsch) and digested in a microwave (Milestone, Digestor/Dring Ethos 900). A sample of about $0.5 \mathrm{~g}$ was accurately weighed into a PTFE pressure vessel and $7 \mathrm{~mL}$ of $\mathrm{HNO}_{3}(65 \%)$, $0.5 \mathrm{~mL}$ of $\mathrm{HF}(50 \%)$, and $2 \mathrm{~mL}$ of $\mathrm{H}_{2} \mathrm{O}_{2}$ were added. All glassware and plasticware were previously acidwashed in $3 \mathrm{M} \mathrm{HCl}$, and rinsed in deionized water. Total concentrations of As and P in root, shoots and tomato berries were determined by Inductively Coupled Plasma (ICP - AES, Varian, Liberty 150). Arsenic and $\mathrm{P}$ detection limits provided by this method were 8 and $12 \mu \mathrm{g} \mathrm{L}^{-1}$, respectively. All analysis were carried out in triplicate. In each analytical batch at least, one reagent blank and one internationally certified reference material was included to assess precision and accuracy of the chemical analysis. Certified reference material (Oriental tobacco leaves CTA-OTL-1) was used. Repeated analyses of certified reference material gave $0.588 \pm 0.013 \mathrm{mg} \mathrm{kg}^{-1}$ for As (certified value $0.539 \pm$ $0.060 \mathrm{mg} \mathrm{kg}^{-1}$ ) and $3006 \pm 85 \mathrm{mg} \mathrm{kg}^{-1}$ for P (certified value $\left.2892 \pm 134 \mathrm{mg} \mathrm{kg}^{-1}\right)$.

\subsection{Statistical analysis}

Data analyses were performed with Kaleidagraph 3.6. Treatment effects were determined by analysis of variance. Where necessary, data were transformed logarithmically to stabilize the variance. Differences were considered as statistically significant at $p<0.05$ (Tukey's test).

\section{Results and Discussion}

\subsection{Plant growth and As toxicity}

Plant biomass decreased markedly with increasing As concentration in irrigation water (Table 2). Plants non-fertilized with $\mathrm{P}(\mathrm{P}-)$ and irrigated with solutions containing $0.5,2$ and $4 \mathrm{mg} \mathrm{As} \mathrm{L}^{-1}$ showed a decrease in their biomass of $17 \%, 42 \%$, and $58 \%$, respectively, compared to their own As control treatment. This reduction was less severe $(13 \%, 30 \%$, and $42 \%$, respectively) in the plants fertilized with $\mathrm{P}(\mathrm{P}+)$ (Table 2). Similar results were also obtained on rice (Abedin et al., 2002) and wheat (Liu et al., 2005; Pigna et al., 2009).

The most negative effect due to the higher As exposure interested the roots dry weight. Specifically, P-plants irrigated with the $0.5,2$ and $4 \mathrm{mg} \mathrm{As} \mathrm{L}^{-1}$ solutions showed a reduction of roots biomass of 29 $\%, 65 \%, 74 \%$, respectively, as referred to control treatment; these percentages, in $\mathrm{P}+$ plants, were significantly lower $(4.1 \%, 18 \%, 34 \%$, respectively). Hence, these data indicated that the addition of $\mathrm{P}$ to the system has significantly increased root biomass, regardless As treatment.

Quaghebeur and Rengel (2003) found that by increasing $\mathrm{AsO}_{4}$ concentration in nutrient solution there was a decrease in the roots and shoots dry weight of Holcus lanatus, accentuated when plants were non-fertilized with P. Similar results were also obtained by Pigna et al., (2009) studying the influence of phosphatic fertilizer on wheat plants irrigated with $\mathrm{AsO}_{4}$-contaminated solutions. 
Table 2. Roots, shoots, tomato berries and total biomass in tomato (Solanum lycopersicum cv Piennolo) exposed to four As concentrations in irrigation water $\left(0,0.5,2.0\right.$, and $\left.4.0 \mathrm{mg} \mathrm{L}^{-1}\right)$.

\begin{tabular}{ccccc}
\hline As conc. mg L $^{-1}$ & Roots & Shoots & Tomato berries & Total \\
\hline & & $(\mathrm{g})$ & \\
\hline Control P- & $2.20 \pm 0.06 \mathrm{a}$ & $14.40 \pm 0.80 \mathrm{~b}$ & $12.60 \pm 0.45 \mathrm{c}$ & 29.20 \\
$\mathbf{0 . 5}$ & $1.56 \pm 0.05 \mathrm{C}$ & $13.10 \pm 0.60 \mathrm{bc}$ & $9.50 \pm 0.22 \mathrm{e}$ & 24.16 \\
$\mathbf{2}$ & $0.77 \pm 0.03 \mathrm{~d}$ & $9.10 \pm 0.42 \mathrm{e}$ & $7.00 \pm 0.18 \mathrm{~g}$ & 16.87 \\
$\mathbf{4}$ & $0.58 \pm 0.03 \mathrm{e}$ & $6.40 \pm 0.22 \mathrm{f}$ & $5.30 \pm 0.12 \mathrm{~h}$ & 12.28 \\
Control P+ & $2.40 \pm 0.16 \mathrm{a}$ & $16.30 \pm 0.70 \mathrm{a}$ & $17.40 \pm 1.05 \mathrm{a}$ & 36.10 \\
$\mathbf{0 . 5}$ & $2.30 \pm 0.14 \mathrm{a}$ & $13.90 \pm 0.74 \mathrm{~b}$ & $15.10 \pm 0.90 \mathrm{~b}$ & 31.30 \\
$\mathbf{2}$ & $1.95 \pm 0.10 \mathrm{~b}$ & $12.40 \pm 0.58 \mathrm{C}$ & $10.90 \pm 0.88 \mathrm{~d}$ & 25.25 \\
$\mathbf{4}$ & $1.60 \pm 0.12 \mathrm{c}$ & $11.10 \pm 0.65 \mathrm{~d}$ & $8.40 \pm 0.62 \mathrm{f}$ & 21.10 \\
\hline
\end{tabular}

Data are expressed as mean values $\pm \mathrm{SD}(\mathrm{n}=4)$ and have been analyzed by two-way analysis of variance.

Means followed by the same letter within columns are not significantly different by Tukey's test at the $5 \%$ level.

The dry weight of shoots (stem plus leaves biomass) was markedly influenced by the interaction between As and $\mathrm{P}$ treatments; the shoots biomass decreased with increasing concentration of As in irrigation water, especially in P-plants. Also the tomato berries yield (mass of tomatoes per pot) decreased significantly with higher As exposure. P- plants non-irrigated with As produced $12.60 \mathrm{~g}$ of tomato berries; the same, when irrigated with the most As-contaminated solution (4 $\mathrm{mg} \mathrm{L}^{-1}$ ) realized only $5.30 \mathrm{~g} \mathrm{pot}^{-1}$ (Table 2 ), with a percentage drop of dry weight of $58 \%$. This reduction of yield was less severe in plants fertilized with P (from 17.40 to $8.40 \mathrm{~g} \mathrm{pot}^{-1}$, percentage drop of dry weight of $51 \%$ ).

The presence of $\mathrm{AsO}_{3}$ in the irrigation solutions inhibited tomato plant growth and, consequently, their yield, especially in the absence of P fertilization. The higher production of biomass of the plants fertilized with $\mathrm{P}$ indicated the beneficial role of $\mathrm{P}$ in preventing the toxicity of As promoting the growth of plants. According to Zhao et al. (2009) $\mathrm{PO}_{4}$ and $\mathrm{AsO}_{4}$ are taken up by plant roots through a common carrier, but the $\mathrm{PO}_{4} / \mathrm{AsO}_{4}$ plasma membrane carrier shows a much higher affinity for $\mathrm{PO}_{4}$ than $\mathrm{AsO}_{4}$. Arsenate/ $\mathrm{PO}_{4}$ uptake can be suppressed or minimized when the plants show a sufficient $P$ status, as it seems to be occurred in our $\mathrm{P}+$ plants (as discussed below). The suppression of the high-affinity uptake system could be due to a feed back regulation of the $\mathrm{AsO}_{4} / \mathrm{PO}_{4}$ transporters (Meharg and Macnair, 1992).

Many authors assessed that non-resistant plants can be made more resistant to $\mathrm{AsO}_{4}$ by raising their $\mathrm{P}$ status, as the P is taken more effectively compared to $\mathrm{AsO}_{4}$ (Meharg and Macnair, 1992; Lee et al., 2003). Also in $\mathrm{AsO}_{4}$ resistant plants with high $\mathrm{P}$ status a reduced sensitivity has been observed, which is not due to a difference in $\mathrm{AsO}_{4}$ influx, but is presumably a result of higher cytoplasmatic $\mathrm{P}$ status, decreasing $\mathrm{AsO}_{4}$ toxicity within the cell (Meharg, 1994). The effect of P nutrition on As toxicity could be summarized as follow: 1) high plant $P$ status leads to a down-regulation of the $\mathrm{AsO}_{4} / \mathrm{PO}_{4}$ plasma-lemma transporters, and 2) 
high cellular $\mathrm{PO}_{4}$ levels result in greater competition with $\mathrm{AsO}_{4}$ for biochemical processes where $\mathrm{AsO}_{4}$ substitutes for $\mathrm{PO}_{4}$ (Meharg, 2005).

\subsection{Arsenic concentration and content in tomato plants}

Arsenic concentration in tomato roots, shoots and berries increased with increasing As concentration in irrigation water (Table 3 ). This trend is particularly evident in the roots of the $\mathrm{P}+$ plants. In fact, by increasing As level from 0.5 to $4.0 \mathrm{mg} \mathrm{L}^{-1}$ in irrigation water, the As concentration in the roots increased from 0.68 to 3.85 and from 1.12 to $4.80 \mathrm{mg} \mathrm{kg}^{-1}$, respectively, in $\mathrm{P}$ - and $\mathrm{P}+$ plants (Table 3 ). Similar results were also found by Tao et al. (2006) and Pigna et al. (2009), who studied the effect of $\mathrm{P}$ addition on the As accumulation in wheat plants.

The higher concentration of As in the roots of $\mathrm{P}+$ plants probably occurred because the application of the fertilizer containing $\mathrm{P}$ could have inhibited the $\mathrm{AsO}_{4} /$ $\mathrm{AsO}_{3}$ sorption on the surface of the soil colloids (Violante and Pigna, 2002; Violante et al., 2005) and consequently, promoted the As uptake by plants because of the higher concentration of As in soil solution.

Table 3. Total As concentration (mg kg-1) and content ( $\mu \mathrm{g}$ pot-1) in roots, shoots and berries of tomato (Solanum lycopersicum cv Piennolo) exposed to four As concentrations in irrigation water.

\begin{tabular}{|c|c|c|c|c|c|c|c|}
\hline $\begin{array}{l}\text { As conc. } \\
{\operatorname{mg~} L^{-1}}^{-1}\end{array}$ & Roots & Shoots & $\begin{array}{l}\text { Tomato } \\
\text { berries }\end{array}$ & Roots & Shoots & $\begin{array}{l}\text { Tomato } \\
\text { berries }\end{array}$ & $\begin{array}{c}\text { As } \\
\text { shoots/ } \\
\text { roots }\end{array}$ \\
\hline & \multicolumn{3}{|c|}{ As concentration ( $\left.\mathrm{mg} \mathrm{kg}^{-1}\right)$} & \multicolumn{3}{|c|}{ As content $\left(\mu \mathrm{g} \operatorname{pot}^{-1}\right)$} & \\
\hline $\begin{array}{l}\text { Control } \\
\text { P- }\end{array}$ & $0.16 \pm 0.04 \mathrm{~g}$ & $0.13 \pm 0.03 \mathrm{e}$ & $0.04 \pm 0.01 \mathrm{c}$ & $0.35 \pm 0.03 \mathrm{~h}$ & $1.87 \pm 0.10 \mathrm{f}$ & $0.50 \pm 0.04 \mathrm{f}$ & 0.81 \\
\hline 0.5 & $0.68 \pm 0.06 \mathrm{f}$ & $0.38 \pm 0.04 \mathrm{~d}$ & $0.18 \pm 0.03 \mathrm{ab}$ & $1.06 \pm 0.06 \mathrm{f}$ & $4.98 \pm 0.19 \mathrm{~d}$ & $1.71 \pm 0.08 \mathrm{c}$ & 0.56 \\
\hline 2 & $2.10 \pm 0.14 \mathrm{~d}$ & $0.55 \pm 0.03 \mathrm{c}$ & $0.25 \pm 0.04 \mathrm{a}$ & $1.61 \pm 0.08 \mathrm{e}$ & $5.00 \pm 0.22 \mathrm{~d}$ & $1.75 \pm 0.11 \mathrm{c}$ & 0.26 \\
\hline 4 & $3.85 \pm 0.16 b$ & $0.79 \pm 0.07 \mathrm{a}$ & $0.28 \pm 0.04 \mathrm{a}$ & $2.23 \pm 0.13 \mathrm{~d}$ & $5.05 \pm 0.18 \mathrm{~d}$ & $1.48 \pm 0.10 \mathrm{~d}$ & 0.20 \\
\hline $\begin{array}{c}\text { Control } \\
\mathrm{P}+\end{array}$ & $0.20 \pm 0.03 \mathrm{~g}$ & $0.14 \pm 0.02 \mathrm{e}$ & $0.04 \pm 0.01 \mathrm{c}$ & $0.48 \pm 0.04 \mathrm{~g}$ & $2.28 \pm 0.10 \mathrm{e}$ & $0.70 \pm 0.04 \mathrm{e}$ & 0.70 \\
\hline 0.5 & $1.12 \pm 0.07 \mathrm{e}$ & $0.42 \pm 0.04 \mathrm{~d}$ & $0.15 \pm 0.02 b$ & $2.58 \pm 0.12 \mathrm{c}$ & $5.84 \pm 0.24 \mathrm{c}$ & $2.27 \pm 0.10 \mathrm{a}$ & 0.37 \\
\hline 2 & $2.90 \pm 0.12 \mathrm{c}$ & $0.64 \pm 0.06 \mathrm{~b}$ & $0.19 \pm 0.03 \mathrm{ab}$ & $5.65 \pm 0.18 b$ & $7.93 \pm 0.31 \mathrm{~b}$ & $2.07 \pm 0.11 \mathrm{~b}$ & 0.22 \\
\hline 4 & $4.80 \pm 0.15 \mathrm{a}$ & $0.85 \pm 0.06 \mathrm{a}$ & $0.22 \pm 0.03 \mathrm{a}$ & $7.68 \pm 0.26 \mathrm{a}$ & $9.43 \pm 0.44 \mathrm{a}$ & $1.85 \pm 0.08 \mathrm{c}$ & 0.18 \\
\hline
\end{tabular}

Data are expressed as mean values \pm SD $(n=4)$ and have been analyzed by two-way analysis of variance. Means followed by the same letter within columns are not significantly different by Tukey's test at the $5 \%$ level.

Similarly, As content $\left(\mu \mathrm{g}\right.$ pot $\left.^{-1}\right)$ also increased with increasing As concentration in irrigation water and $\mathrm{P}$ application (Table 3). Although the $\mathrm{P}+$ plants showed a higher As content than P- plants, in all their tissues, the alleviation of As toxicity would be attributed to the greater dilution of the As in the greater biomass produ- ced by these plants. This aspect is particularly evident in Figure 1, which shows ratios between the As content in tomato berries and their biomass as a function of As treatment. Regardless As level in the irrigation water, $\mathrm{P}$ application has determined a reduction of these ratios, confirming that a greater dilution of the As in the be- 
rries biomass occurred in the plants fertilized with P. In addition, a more evident reduction of this ratio between the $\mathrm{P}$ - and $\mathrm{P}+$ plants (Figure 1) has been determined in the treatments with higher As levels $(2.0$ and $4.0 \mathrm{mg}$ $\left.\mathrm{L}^{-1}\right)$ versus the lowest one $\left(0.5 \mathrm{mg} \mathrm{L}^{-1}\right)$.

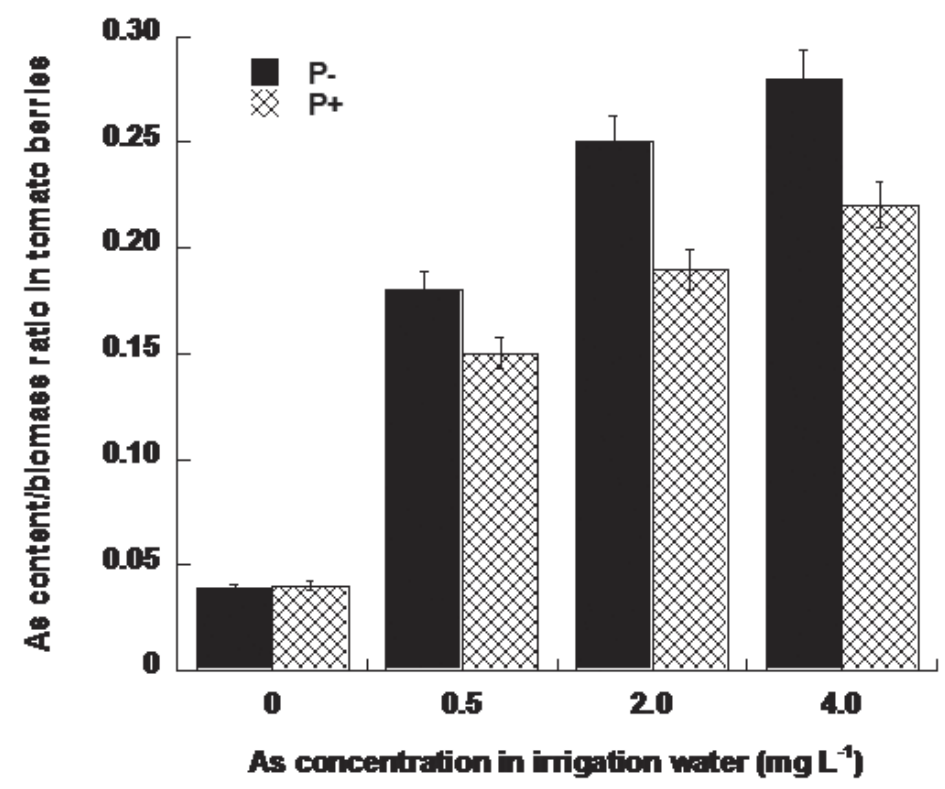

Figure 1. Arsenic content/biomass ratio in tomato berries exposed to four As concentrations in irrigation water $(0,0.5,2.0$ and $4.0 \mathrm{mg} \mathrm{L}-1)$.

The better $\mathrm{P}$ nutritional status of $\mathrm{P}+$ plants has also allowed to limit the traslocation of As from roots to aboveground plant tissues. The higher the As concentration in irrigated water, the higher the As content in tomato berries; however, this content has never reached hazardous values, indicating a little accumulation of As in the tomato berries; in addition, $\mathrm{P}$ application has further limited the As accumulation in tomato berries, highlighting the crucial role of $\mathrm{P}$ in reducing the translocation of As toward tomato berries (Table 3).

The ratios between the As concentration in shoots and roots decreased with increasing As concentration in irrigation water and in $\mathrm{P}+$ plants (Table 3). These results demonstrate that the As concentration in the roots increased more rapidly than that in the shoots; most of the As absorbed by tomato plants, in fact, was accumulated in roots, whereas only a small amount of the toxic element was translocated to the tomato berries; in addition, $\mathrm{P}$ application contributed to enhance this positive trend. In a similar experiment on tomato plants, Carbonell-Barrachina et al. (1997) found that the $83.2 \%$ of all the absorbed As remained in the roots, the $16.8 \%$ in the shoots and only $7.3 \%$ was accumulated in the leaves. A recent study (Bliek et al., 2008) reported that $\mathrm{AsO}_{4}$ tolerance in plants is dependent on the P nutritional status of the plant. This behaviour is promoted by the activity of $\mathrm{AsO}_{4}$ reduc- 
tase, involved in the reduction of $\mathrm{AsO}_{4}$ to $\mathrm{AsO}_{3}$ and subsequent vacuolar sequestration of As(III)-phytochelatin complex.

\subsection{Phosphorus concentration and content in tomato plants}

The concentration $\left(\mathrm{g} \mathrm{kg}^{-1}\right)$ and content $\left(\mathrm{mg} \mathrm{pot}^{-1}\right)$ of $\mathrm{P}$ in roots, shoots and tomato berries are reported in Table 4. Phosphorus concentration in roots of the tomato plants significantly increased with $\mathrm{P}$ application and by increasing level of As in irrigation water. The concentration of $\mathrm{P}$ increased from $1.16 \mathrm{~g} \mathrm{~kg}^{-1}$ (As control treatment) to $2.30 \mathrm{~g} \mathrm{~kg}^{-1}$ (highest As level) and from 1.65 to $3.40 \mathrm{~g} \mathrm{~kg}^{-1}$, respectively, in $\mathrm{P}$ - and $\mathrm{P}+$ plants (Table 4).

The content of $\mathrm{P}$ in $\mathrm{P}$ - plants roots decreased from $2.55 \mathrm{mg} \mathrm{pot}^{-1}$ (As control treatment) to $1.33 \mathrm{mg} \mathrm{pot}^{-1}$ (highest As level) because of the lower biomass produced by the plants irrigated with higher As levels; vice versa it increased in the roots of the $\mathrm{P}+$ plants, from 3.96 to $5.44 \mathrm{mg} \mathrm{pot}^{-1}$ (Table 4). Similar results were obtained by Meharg (1994) who ascertained that
$\mathrm{PO}_{4}$ is more efficiently taken up and accumulated in plant tissues than $\mathrm{AsO}_{4}$. These findings may explain how tolerant plants can survive at high levels of $\mathrm{AsO}_{4}$ in soil solution and, indeed, how plants grown on Ascontaminated sites are able to obtain enough P to sustain their growth (Meharg, 1994).

The $\mathrm{P}$ concentration and content in tomato shoots decreased markedly with increasing concentration of As in the irrigation solutions, especially in the plants non-fertilized with P. For example, the concentration of $\mathrm{P}$ in the shoots of $\mathrm{P}$ - plants irrigated with solution containing $4 \mathrm{mg} \mathrm{As} \mathrm{L}^{-1}$ was $64 \%$ lower than that of their own As control. Similarly, the content of the As in these plants decreased from 30.24 to $4.80 \mathrm{mg}$ pot $^{-1}$ (Table 4). The same trend was also found in $\mathrm{P}+$ plants, but it was lesser pronounced (percentage drop in $\mathrm{P}$ concentration of $23 \%$ and reduction from 52.16 to $27.20 \mathrm{mg} \mathrm{pot}^{-1}$ of $\mathrm{P}$ content).

The concentration of $\mathrm{P}\left(\mathrm{g} \mathrm{kg}^{-1}\right)$ in tomato berries slightly decreased by higher As exposure, both in Pand $\mathrm{P}+$ plants, while its content $\left(\mathrm{mg} \mathrm{pot}^{-1}\right)$, being related to the biomass, produced more severe decreases in P-plants (Table 4).

Table 4. Total P concentration (g kg-1) and content (mg pot-1) in roots, shoots and berries of tomato (Solanum lycopersicum cv Piennolo) exposed to four As concentrations in irrigation water.

\begin{tabular}{|c|c|c|c|c|c|c|c|}
\hline $\begin{array}{l}\text { As conc. } \\
{\text { mg } L^{-1}}^{-1}\end{array}$ & Roots & Shoots & $\begin{array}{l}\text { Tomato } \\
\text { berries }\end{array}$ & Roots & Shoots & $\begin{array}{l}\text { Tomato } \\
\text { berries }\end{array}$ & $\begin{array}{c}\text { P shoots/ } \\
\text { roots }\end{array}$ \\
\hline & \multicolumn{3}{|c|}{$P$ concentration $\left(\mathrm{g} \mathrm{kg}^{-1}\right)$} & \multicolumn{3}{|c|}{$P$ content $\left(\mathrm{mg} \mathrm{pot}^{-1}\right)$} & \\
\hline $\begin{array}{l}\text { Control } \\
\text { P- }\end{array}$ & $1.16 \pm 0.03 \mathrm{~g}$ & $2.10 \pm 0.10 \mathrm{~d}$ & $6.40 \pm 0.18 b$ & $2.55 \pm 0.12 \mathrm{c}$ & $30.24 \pm 1.40 \mathrm{c}$ & $80.64 \pm 3.6 \mathrm{c}$ & 1.81 \\
\hline 0.5 & $1.35 \pm 0.05 \mathrm{f}$ & $1.90 \pm 0.06 \mathrm{e}$ & $6.30 \pm 0.26 \mathrm{~b}$ & $2.10 \pm 0.10 \mathrm{~d}$ & $24.89 \pm 1.30 \mathrm{~d}$ & $59.85 \pm 2.5 \mathrm{e}$ & 1.41 \\
\hline 2 & $1.78 \pm 0.06 \mathrm{~d}$ & $1.00 \pm 0.04 \mathrm{f}$ & $6.12 \pm 0.24 b$ & $1.37 \pm 0.08 \mathrm{e}$ & $9.10 \pm 0.40 \mathrm{e}$ & $42.84 \pm 1.9 \mathrm{~g}$ & 0.56 \\
\hline 4 & $2.30 \pm 0.12 \mathrm{c}$ & $0.75 \pm 0.02 \mathrm{~g}$ & $5.90 \pm 0.22 \mathrm{bc}$ & $1.33 \pm 0.06 \mathrm{e}$ & $4.80 \pm 0.30 \mathrm{f}$ & $31.27 \pm 0.9 \mathrm{~h}$ & 0.33 \\
\hline $\begin{array}{c}\text { Control } \\
\text { P+ }\end{array}$ & $1.65 \pm 0.04 \mathrm{e}$ & $3.20 \pm 0.09 \mathrm{a}$ & $7.20 \pm 0.24 \mathrm{a}$ & $3.96 \pm 0.15 b$ & $52.16 \pm 2.10 \mathrm{a}$ & $125.30 \pm 5.60 \mathrm{a}$ & 1.94 \\
\hline 0.5 & $2.22 \pm 0.09 \mathrm{c}$ & $2.70 \pm 0.07 \mathrm{~b}$ & $6.90 \pm 0.20 \mathrm{a}$ & $5.11 \pm 0.20 \mathrm{a}$ & $37.53 \pm 1.70 \mathrm{~b}$ & $104.20 \pm 4.30 \mathrm{~b}$ & 1.22 \\
\hline 2 & $2.90 \pm 0.13 b$ & $2.60 \pm 0.08 \mathrm{~b}$ & $6.65 \pm 0.18 \mathrm{ab}$ & $5.65 \pm 0.25 \mathrm{a}$ & $32.24 \pm 1.40 \mathrm{c}$ & $72.48 \pm 3.10 \mathrm{~d}$ & 0.90 \\
\hline 4 & $3.40 \pm 0.16 \mathrm{a}$ & $2.45 \pm 0.08 \mathrm{c}$ & $6.40 \pm 0.22 b$ & $5.44 \pm 0.28 \mathrm{a}$ & $27.20 \pm 1.20 \mathrm{~d}$ & $53.76 \pm 2.30 \mathrm{f}$ & 0.72 \\
\hline
\end{tabular}

Data are expressed as mean values $\pm \mathrm{SD}(\mathrm{n}=4)$ and have been analyzed by two-way analysis of variance. Means followed by the same letter within columns are not significantly different by Tukey's test at the $5 \%$ level. 


\section{Conclusion}

The results of this study confirm the important role of $\mathrm{P}$ fertilization in minimizing the negative effects due to the As toxicity. The addition of this important nutrient has also determined a limited translocation of the toxic element from roots to aboveground plant tissues. Hazardous levels of As were not found in tomato berries, which are the edible part of the plant, especially in plant fertilized with $P$. This aspect has practical importance for the As-contaminated agricultural systems, in which adequate production techniques are required to avoid stunted growth of the food plants, severe yield losses and low food quality.

\section{Acknowledgments}

This study was supported by the Italian Research Program of National Interest (PRIN 2008).

\section{References}

Abedin, M.J., Cresser, M.S., Meharg, A.A., Feldmann, J., Cotter-Howells, J. 2002. Arsenic accumulation and metabolism in rice (Oryza sativa L.). Environ. Sci. Technol. 36, 962-968.

Agroalimentare News. 2011. Website: http://www. agroalimentarenews.com/

Bliek, T., Bleeker, P.M., Vooijs, R., Arnetoli, M., Schat, H. 2008. The role of arsenate reductase in arsenate toxicity and tolerance in plants. Presented in 20th New Phytologist Symposium "Arsenic: Unravelling its metabolism and speciation in plants", Aberdeen, Scotland, UK.

Carbonell-Barrachina, A.A., Burlo, F., Burgos-Hernandez, A., Lopez, E., Mataix, J. 1997. The influence of arsenite concentration on arsenic accumulation in tomato and bean plants. Scientia Horticulturae. 71, 167-176.
Chakrabarti, D., Rahman, M.M., Paul, K., Chowdhury, U.K., Sengupta, M.K., Lodh, D. 2002. Arsenic calamity in the Indian subcontinent. What lessons have been learned?. Talanta. 58, 3-22. Frankenberger, W.T. Jr. 2002. Environmental chemistry of arsenic. New York: Marcel Dekker, p. 391.

Hanada, S., Nakano, M., Saitoh, H., Mochizuki, T. 1975. Studies on the pollution of apple orchard surface soils and its improvement in relation to inorganic spray residues. I. Bulletin of the Faculty of Agriculture, Hirosaki University. 25, 13-17.

Jackson, M.L. 1974. Soil chemical analysis - Advanced course, 2nd Soil Survey Laboratory Staff. 1996. Soil survey laboratory methods. Jackson, M.L. (ed) Madison, WI.

Jiang, Q.Q., Singh, B.R. 1994. Effect of different forms and sources of arsenic on crop yield and arsenic concentration. Water Air Soil Pollut. 74, 321-343.

Lee, D.A., Chen, A., Schroeder, J.I. 2003. Ars1, an Arabidopsis mutant exhibiting increased tolerance to arsenate and increased phosphate uptake. Plant J. 35, 637-646.

Liu, X., Zhang, S., Shan, X., Zhu, Y.G. 2005. Toxicity of arsenate and arsenite on germination seedling growth and amylolytic activity of wheat. Chemosphere. 61, 293-301.

Lu, Y., Dong, F., Deacon, C., Chen, H-J., Raab, A. Meharg, A.A. 2010. Arsenic accumulation and phosphorus status in two rice (Oryza sativa L.) cultivars surveyed from fields in South China. Environ. Poll. 158, 1536-1541.

Mandal, B.K., Suzuky, K.T. 2002. Arsenic round the world: a review. Talanta. 58, 201-235.

Meharg, A.A., Macnair, M.R. 1992. Suppression of the high affinity phosphate uptake system a mechanism of arsenate tolerance in Holcus lanatus L. J. Exp. Bot. 43, 519-524. 
Meharg, A.A. 1994. Integrated tolerance mechanisms constitutive and adaptive plant responses to elevated metal concentrations in the environment. Plant Cell Environ. 17, 989-993.

Meharg, A.A., Hartley-Whitaker, J. 2002. Arsenic uptake and metabolism in arsenic resistant and non resistant plant species. New Phytol. 154, 29-43.

Meharg, A.A., Rahman, M.M. 2003. Arsenic contamination of Bangladesh paddy field soils: implication for rice contribution to arsenic consumption. Environ. Sci. Technol. 37, 229-234.

Meharg, A.A. 2005. Mechanism of plant resistance to metal and metalloid ions and potential biotechnological applications. Plant Soil. 274, 163-174.

Naidu, R., Smith, E., Owens, G., Bhattacharya, P., Nadebaum, P. 2006. Managing Arsenic in the environment from soil to human. CSIRO publishing, Melbourne, Australia.

Peryea, F.J. 1998. Phosphate starter fertilizer temporarily enhances soil arsenic uptake by apple trees grown under field conditions. Hortic. Sci. 33, 826-829.

Pigna, M., Cozzolino, V., Caporale, A.G., Mora, M.L., Di Meo, V., Jara, A.A. and Violante, A. 2010. Effect of phosphorus fertilization on arsenic uptake by wheat grown in polluted soils. J. Soil Sci. Plant Nutr. 10 4, 428-442.

Pigna, M., Cozzolino, V., Violante, A., Meharg, A.A. 2009. Influence of phosphate on the arsenic uptake by wheat (Triticum durum L.) irrigated with arsenic solutions at three different concentrations. Water Air Soil Poll. 197, 371-380.

Quaghebeur, M., Rengel, Z. 2003. The distribution of arsenate and arsenite in shoots and roots of Holcus lanatus is influenced by arsenic tolerance and arsenate and phosphate supply. Plant Physiol. $132,1600-1609$.
Roychowdhury, T., Tokunaga, H., Uchino, T., Masanori, A. 2005. Effect of arsenic-contaminated water on agricultural land soil and plants in West Bengal, India. Chemosphere. 58, 799-810.

Small, H.G., McCants, C.B. 1962. Influence of arsenic applied to the growth media on the arsenic content of fluecured tobacco. Agron. J. 54, 129-133.

Smith, E., Naidu, R., Alston, A.M. 1998. Arsenic in the soil environment: A review. Adv. Agron. 64, 149-195.

Tao, Y., Zhang, S., Yuan, W.J., Shan, X.Q. 2006. Effect of oxalate and phosphate on the release of arsenic from contaminated soils and arsenic accumulation in wheat. Chemosphere. 65, 1281-1287.

Violante, A., Pigna, M. 2002. Competitive sorption of arsenate and phosphate on different clay minerals and soils. Soil Sci. Soc. Am. J. 66, 1788-1796.

Violante, A., Pigna, M., Del Gaudio, S. 2005. Adsorption-desorption processes of arsenate in soil environments. In: P.M. Huang, J.M. Bollag, A. Violante, P. Vityakon (eds). Soil abiotic \& biotic interactions and the impact on the ecosystem \& human welfare. Science Publishers, Enfield, NH, USA, pp: 269-299.

Williams, P.N., Price, A.H., Raab, A., Hossain, S.A., Feldmann, J., Meharg, A.A. 2005. Variation in arsenic speciation and concentration in paddy rice related to dietary exposure. Environ. Sci. Techn. 39, 5531-5540.

World Health Organization (WHO). 2004. Guidelines for drinking water $3^{\text {rd }}$ Edition.

Zhao, F.J., Ma, J.F., Meharg, A.A., McGrath, S.P. 2009. Arsenic uptake and metabolism in plants. New Phytol. 181, 777-794. 